Vol. 23, No. 2, September 2020, hlm. 105-114

p-ISSN: 1410-9344; e-ISSN: 2549-5631

homepage: http://journals.ums.ac.id/index.php/warta

\title{
Development of Self-Funded Water Supply for People of Sidomulyo, Sragen Using Deep Well with Submersible Pump
}

\author{
${ }^{1}$ Agus Ulinuha, ${ }^{1}$ Umar Hasan, ${ }^{2}$ Wijianto Wijianto \\ ${ }^{1}$ Program Studi Elektro \\ ${ }^{2}$ Program Studi Teknik Mesin \\ Universitas Muhammadiyah Surakarta \\ Email : Agus.Ulinuha@ums.ac.id
}

\begin{tabular}{l}
\multicolumn{1}{c}{ Article Info } \\
\hline Submitted: 2 January 2020 \\
Revised: 8 January 2020 \\
Accepted: 24 March 2020 \\
Published: 7 April 2020 \\
Keywords : Water availability, \\
Submersible pump, Deep well, \\
Economic aspect
\end{tabular}

Economic aspect

Kata Kunci : Ketersediaan Air, Submersible Pump, Sumur Dalam, Aspek Ekonomi

\begin{abstract}
The availability of water is a problem for the people of Sidomulyo, Krikilan, Sragen at dry season. Having a higher altitude than other areas causes the water from the government water supply company difficult, reaching the area, particularly at the peak time. Some people using water from bore water also have the same problem of limited water. It is, therefore, necessary to bore the deep well for getting enough water to satisfy the people's needs. The deep level of the well should be enough to assure not to absorb the water source of people's well. In this program, the well with the deep of $81 \mathrm{~m}$ is bored, and PVC water pipes are placed inside the hole assuring only the deep bore water is taken out. This is aimed to avoid taking water from the low-level source, which may reduce the water going to the people's well. For pumping purposes, the submersible electric pump is used. It is $3 \mathrm{hp}$, 2500-Watt pump with a capacity of $18 \mathrm{~m}^{3}$ per hour. From the 3-day pumping test, the capacity of well is very enough to provide water needs for the 34 families of Sidomulyo. High-water storage with the dimension of $(2.4 \times 2.4 \times 2) \mathrm{m}^{3}$ has been constructed with a height of $7.4 \mathrm{~m}$ to the tank base. The power source is currently from the electrical utility but is planned will be from Solar Photovoltaic. From a financial perspective, the revenue from the water bill will support community activities.
\end{abstract}

Abstrak
Ketersediaan air bagi warga Dukuh Sidomulyo, Krikilan, Sragen
merupakan persoalan rutin setiap musim kemarau. Dukuh yang
berada pada sisi utara jalan nasional Solo - Surabaya tersebut memiliki
kontur yang lebih tinggi dibandingkan wilayah sekitarnya, sehingga air
dari PDAM Masaran sulit menjangkau wilayah tersebut pada musim
kemarau terutama pada jam-jam pemakaian yang padat. Sebagian
warga yang memanfaatkan air sumur juga mengalami kendala, karena
kondisi sumur yang juga kering. Diperlukan solusi penyediaan air


secara mandiri dengan menggali sumur serta menampung airnya dalam tandon. Karena sejumlah warga juga memiliki sumur, maka sumur yang digali harus cukup dalam sehingga tidak mengganggu pasokan air bagi sumur warga. Dalam kegiatan pengabdian ini, dilakukan penggalian sumur dengan kedalaman $81 \mathrm{~m}$ dan pada dinding lubang sumur dipasang selubung pipa PVC untuk memastikan sumber air yang ditarik merupakan mata air sisi dalam, sehingga tidak mengganggu pasokan air bagian atas yang merupakan sumber mata air pada sumur warga. Penarikan air dilakukan dengan pompa celup (submersible pump) berkekuatan $3 \mathrm{hp}, 2500$ Watt dengan kemampuan debit $18 \mathrm{~m}^{3} /$ jam. Berdasarkan uji pemompaan selama 3 hari, kapasitas air dirasakan cukup untuk memenuhi kebutuhan $34 \mathrm{KK}$ warga Dukuh. Untuk keperluan penampungan air, dibangun tandon berdimensi $(2,4 \times 2,4 \times 2) \mathrm{m}^{3}$ dengan ketinggian 7,4 m sampai dengan dasar tandon. Sumber energi pada saat ini berasal dari PLN, namun direncanakan, diperoleh dari sel surya. Keberadaan sumur tersebut juga diharapkan cukup prospektif sebagai sumber pendapatan dukuh yang bersumber dari retribusi. Meskipun diharapkan lebih murah dari tarif PDAM, retribusi tersebut diharapkan cukup mendukung kegiatan warga setelah dikurangi biaya pemeliharaan.

\section{INTRODUCTION}

Sidomulyo RT 24B/RW 05 is a district under the village of Krikilan, Masaran, in the regency of Sragen. This area is located near to the national road from the city of Surakarta to East Java. Geographically, the district has a higher altitude than other surrounding areas. This condition makes Sidomulyo secure from the flood at the rainy season. However, in the dry season, the people of Sidomulyo facing the difficulty of getting fresh water. Bore water from the people's well is not sufficient to satisfy the people's needs, while the water from the government water supply company is challenging to reach the area at the peak season of water use. The high elevation of this area causes low pressure of water flow at the peak season since many people use the water at the same time.

The majority of the people of Sidomulyo are not native people of the area. They are from different areas and living in the area due to the reason of working place and marriage. There are 34 families at Sidomulyo, with an average of 4 persons at every family. The financial capability of the people is about higher than the people in the surrounding areas. The relation among people is good where they always help each other for the problem that they may face. They are happy to work together for the project that they plan together. They have good understanding leading to a very peaceful situation. Social activities are regularly carried out like gathering, regular meetings, Islamic lectures, and some other agendas that they plan.

Since their financial capability is good enough, the people of Sidomulyo tend to have a higher consumption of electricity and water. The people of Sidmulyo use several devices and apparatus that consume some electric power. A number of houses use an air conditioner and water heater to have their life comfortable. The domestic electrical capacity is mainly at the class of R- 2 with a capacity of 900 VA. Similar to electric consumption, the use of water is comparatively high for the people of Sidomulyo. Besides domestic needs, the water is used to clean up the car that they have. Almost all of the house has a water supply from the government water supply company. Based on the data collected from some people of Sidomulyo, the bill for water use is about IDR 150,000 / month. This number is high enough, indicating that the water consumption of the Sidomulyo people is high.

In the dry season, the people of Sidomulyo experience the problem of water supply, where the supply may not sustain, or the water supply 
pressure is very low. The low pressure of water supply causes the water may not be useful for some purposes like showering and washing. As previously discussed, this condition happens at peak times when many people use water at the same time. This causes its pressure very low and difficult to reach Sidomulyo due to its higher altitude. Because of these problems, the people of Sidomulyo, with the support of the community development program, establish a deep well including the high placed water storage. At the time when this paper is composed, the well and the storage have been completely constructed. To lift the water to the storage, a 3-horsepower (hp) submersible pump is employed (Intelisano, 2018). A test has been done to evaluate the capacity of water that can be provided and the performance of the pump. It was recorded that from the 3-day operation, the capability of the well is remarkably enough to fulfill the water need for the people of Sidomulyo.

Once the system is established and able to operate properly, the next step is developing the energy management system. It is about how to provide the water with minimum energy, therefore, minimizes the cost. The water pump employed in this system is a 3-hp submersible pump that requires the power of $2500 \mathrm{Watt}$. This pump enables providing high water debit yet requires high power leading to high operational cost. Therefore, it is necessary to control the pump operation such that it may optimize the operational cost. An electronic-based control may be developed and used to control the operation of the pump by determining when the pump should be switch on/off that leads to minimum operating cost. For this purpose, some water level sensors are used to detect the level of water, and its measurements are processed by the controller to decide if the pump should switch on/off. On the other hand, the controller should provide a possibility of adjustment so that the water level may be altered that implies the pump may be operated according to the specific purpose. The change is also aimed to enable the pump operating with an optimal schedule resulting in minimum energy consumption.

For the purpose of plumbing from water storage to the customers, the design and modeling of the tracks are necessary to determine the most optimal paths. The objective of the design is to find the most efficient network, which minimizes the investment cost, suppresses the pressure loss, and makes the maintenance easier (Dwijaya \& Irianto, 2019; Yosefa \& Indarjanto, 2017). It is necessary to involve the people of Sidomulyo to carry the job out under the supervision of experts designing the plumbing tracks. A committee has been set up to be in charge of the tasks, including site survey, design the paths, and implement the design. The program of community development does not cover the cost for materials procurement, plumbing works, and establishing a connection to the house installation. Contribution from the people of Sidomulyo is therefore required. From the meeting on February $5^{\text {th }}, 2020$, it was approved that every house/family must contribute the fee of IDR 550,000 for plumbing material and installation works. The purchase of meter for water consumption measurement is excluded from this fee.

The entire cost, including energy consumption, plumbing infrastructure, and its maintenance, should be considered to determine the bill for water consumption together with some additional profit to support the community activities of Sidomulyo people. To set up this decision, some agreement had been approved by the people of Sidomulyo at the meeting on February $5^{\text {th, }} 2020$. However, the price for water use is expected to be less than that of the government water supply company.

From the whole program of establishing the self-funded water supply, the people of Sidomulyo are hoping that the problem of water availability may be solved, particularly in the dry season. The optimal operation management of the system is expected to provide some fee for people's everyday activities. The developed system, as well as system management, will be the role model that may also be applied to the other areas. I

In the future, to reduce energy consumption, some Solar Photovoltaic panels will be used as a power supply (Aliyu et al., 2018; Li et al., 2017)there can be problems of reliability and availability where fuel supply is erratic and expensive, high maintenance cost, and short life expectancy. These and recent concerns for the environment associated with the diesel engines 
call for a viable alternative source of power for irrigational water pumping. Renewable energy sources have gained a lot of attention as a replacement for fossil fuels or as a supplement in hybrid systems. Solar-powered (photovoltaic. However, considering the pump capacity, the need for the panel is many. On the other hand, the pump will not operate all the time, meaning that the pump will not always use the power generated by the panel. Therefore, the panel installed will not be as high as the pump's need, but the power generated by the panel will be saved in the battery. When the pump is on, the power will be taken from the panel and battery. But when the pump is off, the battery is charged by the panel. Some additional equipment is required, including battery, solar charger controller, and inverter. This scheme will also enable the pump to operate at night using energy stored in a battery.

\section{METHOD}

The system of water supply for people of Sidomulyo is schematically shown in Figure 1. The flowchart of Figure 2 indicates the steps of establishing the system. From the system, design for constructing the self-funded water supply should consider some aspects, including the deep of well, the diameter of well, the size of the pump, and the size of water storage. The size of the pipe and the total length of plumbing need to also be estimated. However, the total water need of Sidomulyo people should be firstly recorded, as this is the main concern for determining the deep and diameter of well, the size of water storage, and the pump size. These parameters are considered to make the pump not frequently run, which may lead to high power consumption cost and reduce the pump's lifetime. Another factor to consider is the deep of well should be enough to assure that the water source taken from the well is from the deepwater source that will not reduce the water source of people's well. The investment cost for establishing the system will be another factor to consider in this context.

With the outlined steps in hand, some activities may be carried out. The first step to do is deciding the location of well. According to the decision taken in a meeting involving people of Sidomulyo, the location of well is on the north side of Sidomulyo community building and on the east side of the security post of Sidomulyo.
This location is selected because this is the government property that may be used for a common purpose. The location in the middle of people's life-place is another reason. The altitude of the selected location is about higher than other areas around the life-place that will enable distributing the water to the all house with sufficient pressure. The aforementioned reasons are considerations where the well is located. To avoid any complaint in the future, the request for approval from the formal government has been submitted and the request has been officially approved.

The following step for establishing the system is tunneling the well. It had been discussed and approved that the deep level of the well is a minimum of $80 \mathrm{~m}$. This level is taken to assure that the water taken out from the well is not that from the water source of people's well. For tunneling, the well, a mechanical device driven by a diesel engine was used. The deep level of the well that can be achieved is $81 \mathrm{~m}$, which is deeper than the agreement. The diameter of the well is four dm, and the PVC pipe of the size is placed inside the hole to assure only the deepwater source is pumped out. All of the jobs were carried out following the agreements to avoid any problem in the future. It was about ten days required to bore the well.

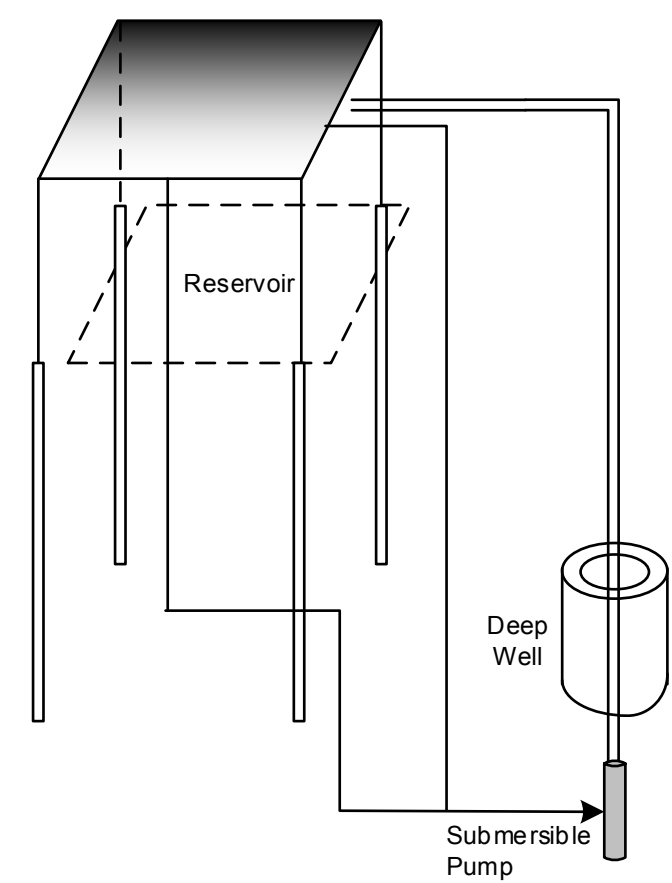

Figure 1. The outline system of water supply 


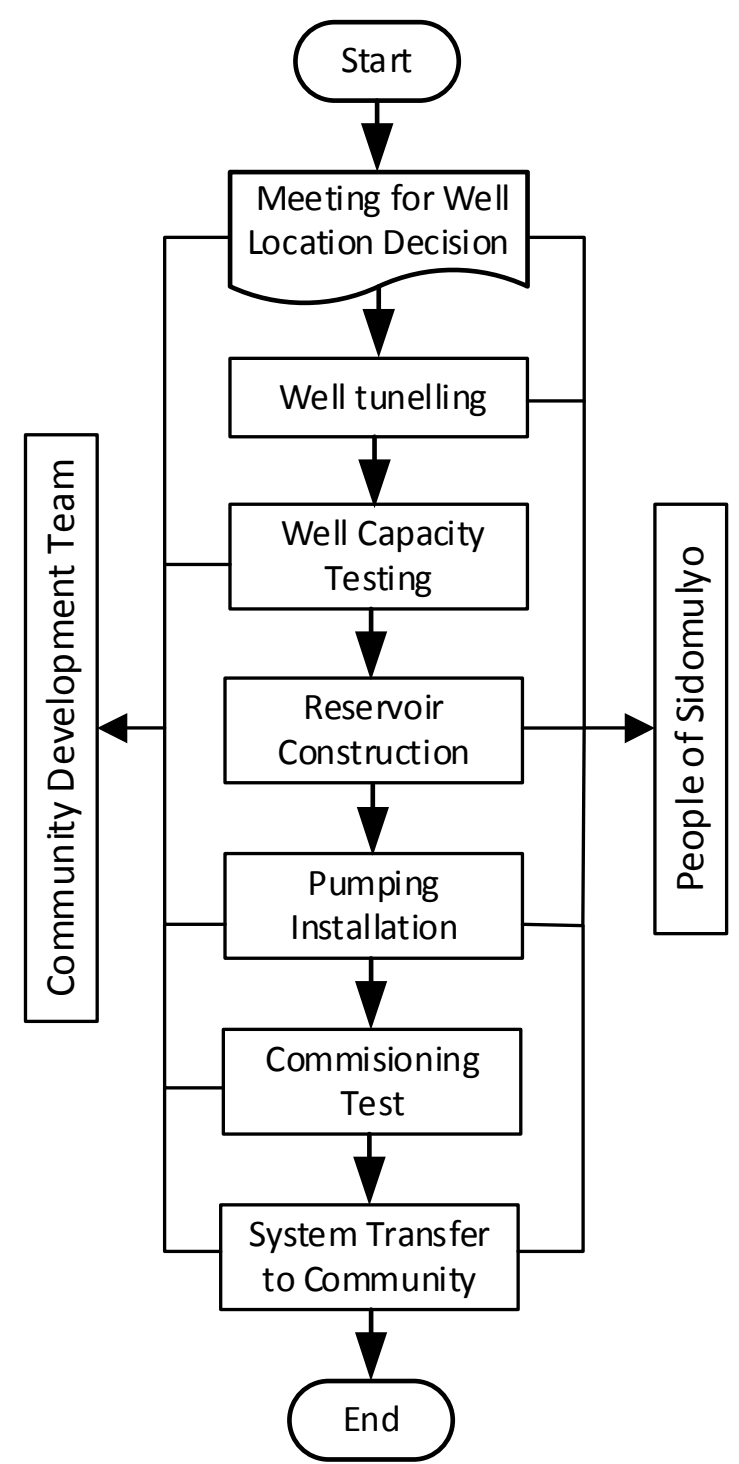

Figure 2. System development Flowchart

Once the well is utterly bored, the capacity of the well to provide sufficient water needs to be tested. The water from the well was therefore pumped out, and it was confirmed that from the 3-day pumping, the well might provide water with big debit without any cutoff. It therefore assures that capacity of the well to provide water for 34 houses will be sufficient.

The construction of water storage would be the next step of this project. The size of water storage should be carefully calculated considering the space available and the volume. The calculation of the storage volume is also based on the requirement that the stored water is enough for the whole people but does not make the pump too often operate, which leads to high power consumption and shortening the equipment lifetime.

Once the storage construction completes, the next stage is a permanent installation of the pump, wiring system, piping, and power supply for the pump. The complete system needs to be tested to observe the performance of the pump in filling the storage and the estimated running time required. The on/off frequency and duration of pump operation should also be taken into account for minimizing power consumption and maximizing pump lifetime.

The final stage after the well and the pump functioning optimally, the complete system including well, water storage, pump, and all related equipment was handed over to the authority of Sidomulyo people to be utilized. However, there is still a work of piping network installation to all houses. The procurement of plumbing materials and the work of piping is not supported by this community development program. Nonetheless, assistance may still be provided by the team of the community development program to design the piping network. Another assistance may be provided by the team in the form of system operation management such that the system enables presenting the maximum benefit for people while giving financial support for community programs.

\section{RESULTS AND DISCUSSION}

Based on the meeting minutes of Sidomulyo people, the location of well was decided. The deep level of the bored well was also decided. It is 81 $\mathrm{m}$ and the concern behind this decision have been previously discussed. The location of well and the work of well tunneling are respectively given in Figure 3 and Figure 4. For the work of tunneling the well some problem was encountered, where 2 big stones were detected during the work. There was no choice instead of hollowing the stones since the work of tunneling the well had achieves the deep of more than $30 \mathrm{~m}$. As a result, the time needed for completing the work of well tunneling was longer than expected. However, the job had been successfully completed and the well may provide sufficient water for Sidomlyo people. 


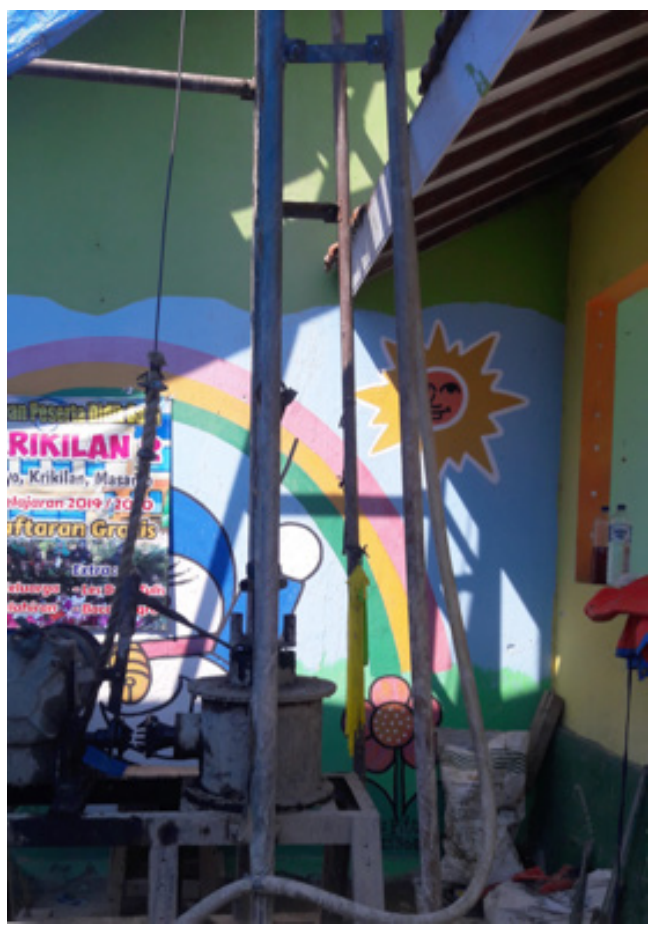

Figure 3. The location of well

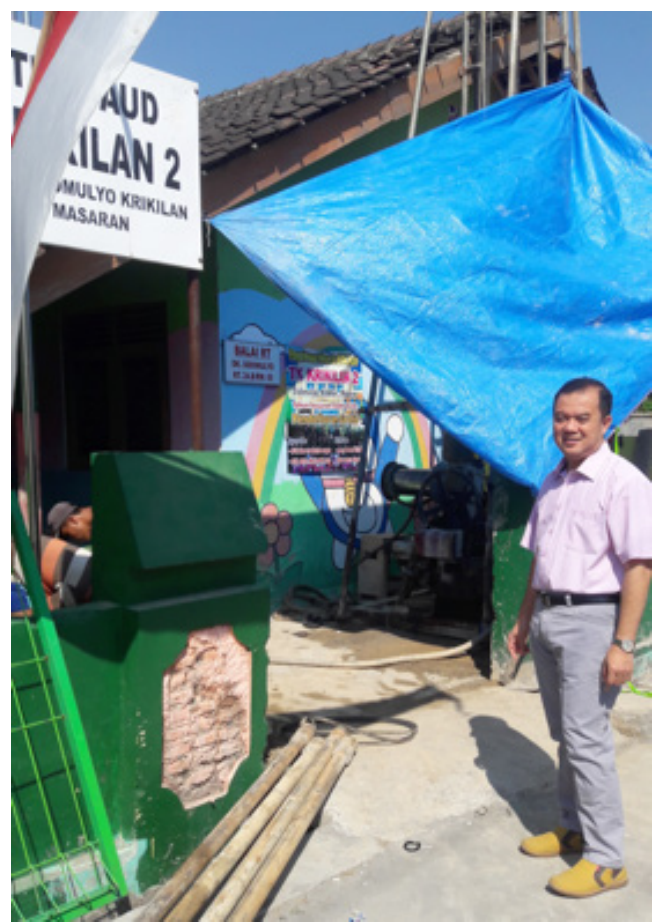

Figure 4. The tunneling process

Once the well was excavated and the PVC pipes with the diameter of $4 \mathrm{dm}$ were inserted to the well's hole, the next process is the test for the well-using pump to measure the water capacity, and also to clean up the water. This is aimed to get the water clean enough, therefore, complying with the requirement to be used by the people.
The installation of the water pump and initial pumping process are respectively shown in Figure 5 and Figure 6 . The pumping for cleaning up the well's water took a long time. The process was carried out until the water coming out from the well is quite clear. It was fortunate since, at the time of the pumping process, there are some rice farmlands were dry and some water were needed to keep the rice alive because it was close to harvest time. Therefore, the dirty water pumped from the well was drained for watering the farmlands. In return, the farmer was happy to pay for the watering since it might save their rice. It should be noted, that the pumping process is also aimed to test the durability of the pump operation.

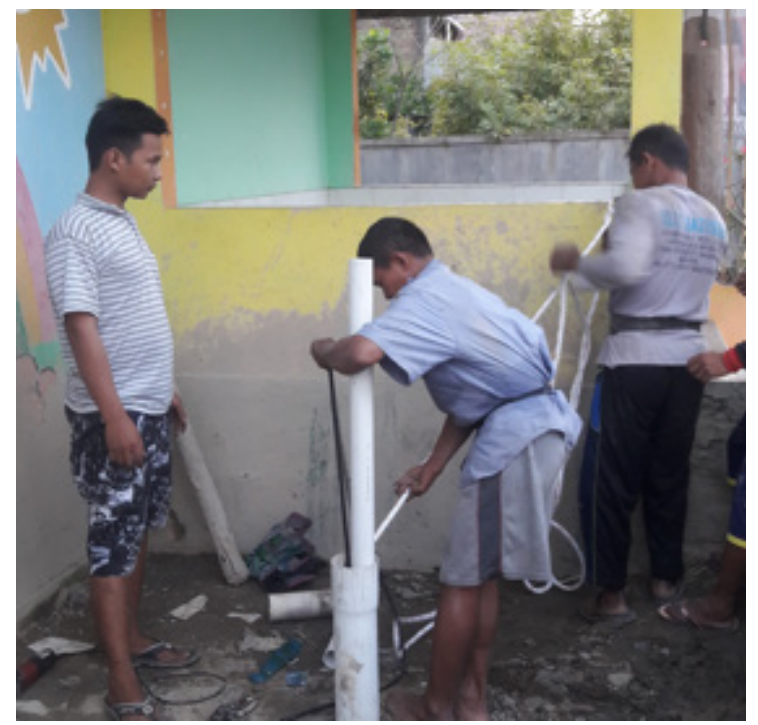

Figure 5. Pump Installation

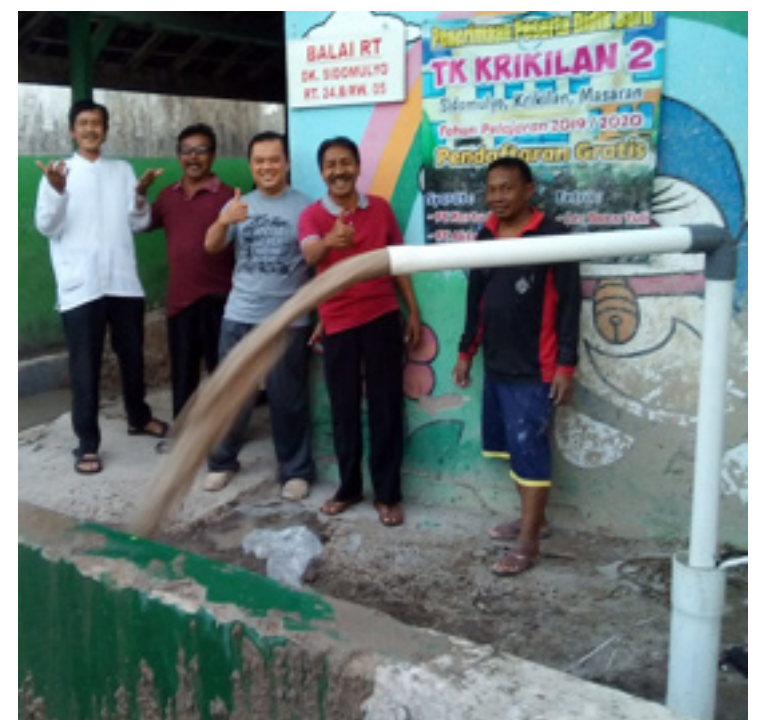

Figure 6. Initial step of water cleaning up 
Based on the assessment of water capacity, the well is estimated to be able to provide the water for 34 families of Sidomulyo. The cleaning up process was carried out by taking the water out from the well and flowing it to the rice farmlands for $3 \times 24$ hours. It was confirmed that the well is able to flow the water continuously for the period. After the 3-day pumping, the water from the well was already clean and clear.

Construction of water storage had been started while the cleaning up the water was on progress. The size of storage is $(w \times l \times h) 2.4 \times$ $2.4 \times 2 \mathrm{~m}^{3}$. The distance from the ground to the storage base (height) is $7.4 \mathrm{~m}$. This height is expected to enable water flowing with sufficient pressure at ground level. To lift the water up to the storage, a 3-hp, $2500 \mathrm{~W}$ submersible pump is employed that may provide the minimum debit of $18 \mathrm{~m}^{3}$ per hour. After completing the storage construction and the submersible pump had been properly installed, the water was initially lifted up to full fill the storage. For the given size, the time required to fill the storage was about 30 minutes. Once the storage was filled, the speed of water going out at the ground level was tested. It was observed that the water flowing at that position was very fast. It is therefore expected that the water may be distributed to Sidomulyo families with sufficient pressure.

Based on the report from the head of the Sidomulyo people community, the average daily water consumption is $0.5 \mathrm{~m}^{3}$ per household. If the consumption is assumed to be $1 \mathrm{~m}^{3}$ per household per day, then the total water consumption for the 34 families of Sidomulyo is $34 \mathrm{~m}^{3}$. The volume of water that can be filled in the storage is:

$\mathrm{v}=2.4 \times 2.4 \times 2=11.52 \mathrm{~m}^{3}$

However, the storage cannot be fully filled with water. If it is assumed that the storage is filled with water up to the height of $1.75 \mathrm{~m}$, then the volume of water in the storage is:

$\mathrm{v}=2.4 \times 2.4 \times 1.75=10.08 \mathrm{~m}^{3}$.

From the operational standpoint, the pump should again run before the water in the storage completely finish. Once the water left is about $25 \%$, then the pump will again operate to lift the water from the well to fill the storage. Therefore, for every pumping operation, the volume of water that should be lifted to the storage is
$75 \% \times 10.08 \mathrm{~m}^{3}=7.56 \mathrm{~m}^{3}$. For the total water consumption of $34 \mathrm{~m}^{3}$ for all Sidomulyo families, the number of pump operation is

Pump operation number $=\frac{34}{7.56}=4.5$ or 5 times per-day

From the test of filling the storage from the empty condition until it is fully filled by water, the time required by the pump is less than 30 minutes. If it is assumed that pump operation time is proportional with the volume of lifted water, then for lifting the water of $7.56 \mathrm{~m}^{3}$, the required time $(t)$ is:

$t=\frac{7.56}{11.52} \times 30=19.7$ minutes

For filling the storage 5-time per-day, the total time required by the pump for the whole day is:

$T_{\text {tot }}=5 \times 19.7=98.5$ minutes

For the use of electrical power from the National Electric Company, the energy consumption $(E)$ of $2500 \mathrm{~W}$ water pump in $\mathrm{kWh}$ may be calculated as follows:

$E=2.5 k W \times \frac{98.5}{60} h=4.1 k W h$ per-day

At the time when this paper was composed, the cost of energy use from the company is less than IDR 2000,-/kWh (Moneysmart, 2019; PLN, n.d.). Therefore, if the tariff of IDR $2000,-/ \mathrm{kWh}$ is considered in this case, the cost of electric energy consumption for pumping the water is 4.1 $x$ IDR $2000=$ IDR 8,200, - per-day. For the water volume of $34 \mathrm{~m}^{3}$, the cost for water pumping is:

Pumping $\cos t=\frac{8,200}{34}=I D R 214.18$

Since the tariff was actually less than IDR $2000,-/ \mathrm{kWh}$, the cost for water pumping as given in eq. (7) would be the maximum figure. However, this cost has not included investment cost and maintenance cost. To determine the tariff applied to the customer, all of the components must be taken into account, yet this should be lower than the tariff from the government water supply company. At the time when this paper is composed, for the use of 10 $\mathrm{m}^{3}$ water from the government water supply company, the bill is more than IDR $40,000,-$. This

Warta LPM, Vol. 23, No. 2, September 2020 
bill includes components including maintenance of water meter. This bill will be the reference for determining the tariff of water used by the people of Sidomulyo. While people may have a continuous water supply with less cost, some extra fees may be saved for supporting the social activities of Sidomulyo people.

When this paper is composed, the tunneling of the well has finished, the test of water debit has also been carried out. The construction of water storage has completed and is has been fully filled with water for checking if there is any leakage. The water pressure at the ground level has been tested, indicating high pressure. It may assure the water may reach the costumer's house with sufficient pressure. In terms of operation, the system, including well, water pump, pipelines, and storage, has normally worked. Nearby, people momentarily use the water-filled to the storage through some temporary connections. This is due to the drought condition during the dry season in the year 2019 is really bad. This bad drought condition is also encountered by people in the different areas outside the Sidomulyo district; therefore, for their water needs, they also use that water by taking it in water containers.

For optimally using the water, the next step is establishing the pipelines to supply the water to the house of Sidomulyo people. The house place of Sidomulyo people is spread and is at different roadside. Furthermore, they are at different levels of altitude. Therefore, the path of the pipeline should be carefully designed. The purpose is the construction of pipelines causes minimum building and road destruction, and the pipeline may feed equal water pressure to the people's house. A meeting on December $5^{\text {th, }}$ 2019, was conducted to discuss the most optimum path of pipelines satisfying the objective with the minimum cost. It should be noted that the cost of pipes construction is not covered by the project of community development, and the people of Sidomulyo should earn by themselves.

The project of community development covers the establishment of the system, including well, water pump, water storage, piping from well to storage, and piping from storage to the ground level for further water distribution. Therefore, once the system has been completely constructed and has worked properly, then it may be transferred to the authority of Sidomulyo people. The transfer was conducted in a meeting involving all Sidomulyo people. The local government of Krikilan village also attended in the meeting and gave some advice on how to sustain the system to operate and provide some benefits for the people of Sidomulyo.

In order to ensure the system operating properly and no problem will be encountered, some persons are appointed to be in charge of the system operation and maintenance. The persons will be selected in a meeting of Sidomulyo people, and the assignment letter will be given for them. A combination of workshops and training will be arranged for them to improve their knowledge and skill on how to operate and maintain the system. The persons in charge will also be required to present the monthly report in a meeting of Sidomulyo people.

For the whole planning of system development, including water distribution, further development planning is the substitution of power source from the Government Electricity Company to the stand-alone renewable energy generation. This is a solar photovoltaic (PV) panel that enables generating electricity from sunlight (Chandel et al., 2017)optimum sizing and the use of electronic controls to improve the efficiency. The intelligent control methods for maximum power point tracking (MPPT. The water pump requires high power yet does not continuously operate. Therefore, the electric energy generated by the solar PV will be saved in a battery and will be used by the pump when the water volume achieves the minimum level (Muhsen et al., 2017). The operation time of the pump at each time to fill the storage is 19.4 minutes, as indicated in Eq. 4, and therefore the remaining time is to charge the battery by electricity from solar PV. It is expected that this power charging will give the battery enough energy for the next pump operation. The saved energy in the battery will also be used for pump operation at night, where the sunlight is unavailable.

For the purpose of saving electrical energy to the battery, a Solar Charging Controller (SCC) is employed to regulate the charging voltage that enables power flow from Solar PV panels to cell and to stop charging when the battery is fully 
charged. (Lokesh Reddy et al., 2017). Since the pump uses AC power, an inverter is employed to convert the $\mathrm{DC}$ power from the battery to $\mathrm{AC}$ power required by a water pump (Koreboina et al., 2017)switched reluctance motor (SRM. The inverter also regulates the voltage and frequency, ensuring the power complies with the pump's requirement.

The system is operated with control devices determining the on/off pump operation based on the volume of water in the storage. When the pump is supplied with the power from the battery, it may happen that the remaining battery capacity is not sufficient for satisfying the power need of the pump. Therefore, this scheme will require a back-up of power from the Government Electricity Company. A mechanism for automatic power transfer will be necessary for automatically switching the power supply from battery to electric grid or vice-versa. It is an Automatic Transfer Switch that enables performing the task (Czarnecki, 2017). This device needs to be developed using some sensor and measurement devices to detect if the remaining battery capacity is no longer sufficient to feed the pump. When the battery capacity increases due to the charging process and is sufficient to supply the pump, then the supply will again be changed to the battery. These transfers can be done, and even the pump is running. It may be noted that the primary power source for pump operation is from the battery, and therefore, as long as the energy saved in the battery is sufficient, then the pump is supplied by the battery. The energy level of the battery is correlated with the voltage, and it may be measured to determine if the supply needs to be switched to the electricity grid.

\section{CONCLUSION}

The establishment self-funded water supply for the people of Sidomulyo has partly completed.
This includes the deep-well, the submersible pump, water storage, local piping, and some basic electricity installations. The system has been tested, indicating that all components have properly worked. According to the assigned job, the team has done all the jobs completely. The next step is installing the pipelines to all of Sidomulyo families so that they can enjoy the water at a cheaper cost. The pipes procurement and its installation is the responsibility of the Sidomulyo people. However, the team of community development can still provide some assistance in determining the most optimal piping tracks and the size of the pipe. The aid may also be provided in the form of training on how to manage the system to also give some profit to support the community activities of Sidomulyo people financially. To reduce the operational cost, the energy supply will be satisfied by renewable energy. It is planned to use Solar Photovoltaic for providing the electricity for the pump. The investment cost of this Solar Photovoltaic is high and seems not to be competitive with using power from Government Electricity Company. This is due to its price is low at this moment. With the possibility of the price increase and considering the long life of Solar Photovoltaic, the use of Solar Photovoltaic becomes more feasible.

\section{ACKNOWLEDGMENT}

The authors would like to acknowledge that this community development program is financially supported by The Directorate of Research and Community Engagement (Direktorat Riset dan Pengabdian Masyarakat/ DRPM) through the scheme of Community Partnership Program (Program Kemitraan Masyarakat/PKM), under the contract number: 501.1/A.3-III/LPPM/XII/2019, the year of 2019.

\section{REFERENCE}

Aliyu, M., Hassan, G., Said, S. A., Siddiqui, M. U., Alawami, A. T., \& Elamin, I. M. (2018). A review of solar-powered water pumping systems. Renewable and Sustainable Energy Reviews, 87, 61-76. https://doi.org/10.1016/j.rser.2018.02.010

Chandel, S. S., Naik, M. N., \& Chandel, R. (2017). Review of performance studies of direct coupled 
photovoltaic water pumping systems and case study. Renewable and Sustainable Energy Reviews, 76, 163-175. https://doi.org/10.1016/j.rser.2017.03.019

Czarnecki, N. A. (2017). Transfer switch for automatically switching between alternative energy source and utility grid (United States Patent No. US9583942B2). https://patents.google.com/patent/ US9583942B2/en

Dwijaya, A., \& Irianto, D. (2019). Desain Dimensi Model Sistem Jaringan Pipa Distribusi Air Baku Dusun Glindah Kidul Desa Glindah Kedamean Gresik Menggunakan Program Aplikasi EPANET v.2.0. (Model Dimensional Design Pipe Network System for Standardized Water Distribution at Glindah District, Glindah Village, Kedamean, Gresik using EPANET Application Program) Rekayasa Teknik Sipil, 2(1). https://jurnalmahasiswa.unesa.ac.id/index.php/rekayasa-teknik-sipil/article/ view/28856

Intelisano, C. (2018). Submersible pump (United States Patent No. US10122235B2). https://patents. google.com/patent/US10122235B2/en

Koreboina, V. B., Narasimharaju, B. L., \& Kumar, D. M. V. (2017). Performance investigation of simplified PWM MPPT approach for direct PV-fed switched reluctance motor in water pumping system. IET Electric Power Applications, 11(9), 1645-1655. https://doi.org/10.1049/iet-epa.2017.0038

Li, G., Jin, Y., Akram, M. W., \& Chen, X. (2017). Research and current status of the solar photovoltaic water pumping system - A review. Renewable and Sustainable Energy Reviews, 79, 440-458. https://doi.org/10.1016/j.rser.2017.05.055

LokeshReddy, M., Kumar, P. J. R. P., Chandra, S. A. M., Babu, T. S., \& Rajasekar, N. (2017). Comparative study on charge controller techniques for solar PV system. Energy Procedia, 117, 1070-1077. https://doi.org/10.1016/j.egypro.2017.05.230

Moneysmart. (2019, August 9). Ada Kompensasi PLN, Berapa Besaran Tarif Listrik yang Resmi Berlaku Sekarang? (There is PLN Compensation, What's the Current Official Electricity Tariff?) MoneySmart Indonesia - Tips dan Cara Mengatur Keuangan, di Sini Tempatnya. https://www.moneysmart.id/ daftar-tarif-listrik-terbaru/

Muhsen, D. H., Khatib, T., \& Nagi, F. (2017). A review of photovoltaic water pumping system designing methods, control strategies and field performance. Renewable and Sustainable Energy Reviews, 68, 70-86. https://doi.org/10.1016/j.rser.2016.09.129

PLN. (n.d.). Tariff Adjustment. Retrieved December 14, 2019, from https://www.pln.co.id/pelanggan/ tarif-tenaga-listrik/tariff-adjustment

Yosefa, F., \& Indarjanto, H. (2017). Analisis Perencanaan dan Pengembangan Jaringan Distribusi Air Bersih di PDAM Tulungagung. (The Analysis on Design and Development of Fresh Water Distribution at the PDAM of Tulungagung) Jurnal Teknik ITS, 6(1), D25-D29-D29. https://doi.org/10.12962/ j23373539.v6i1.21633 